\title{
PENGEMBANGAN BUKU AJAR BAHASA JEPANG BAGI SISWA KELAS V SD TUNAS KASIH NUSA DUA
}

\author{
M. L. G. Purwantini ${ }^{1}$, \\ D. M. S. Mardani ${ }^{2}$, K. E. K. Adnyani ${ }^{3}$ \\ Jurusan Pendidikan Bahasa Jepang \\ Universitas Pendidikan Ganesha \\ Singaraja, Indonesia \\ e-mail: ellygirii59@gmail.com ${ }^{1}$ \\ desak.mardani@undiksha.ac.id² krishna.adnyani@undiksha.ac.id ${ }^{3}$
}

\begin{abstract}
Abstrak
Penelitian ini bertujuan untuk menghasilkan buku ajar yang sesuai dengan kurikulum KTSP dan silabus mata pelajaran bahasa Jepang untuk siswa kelas V di SD Tunas Kasih Nusa Dua. Penelitian ini merupakan jenis penelitian pengembangan (research and development). Penelitian ini dilaksanakan dengan menggunakan rancangan 4-D models. Subjek dalam penelitian ini adalah guru mata pelajaran bahasa Jepang dan siswa kelas V SD Tunas Kasih Nusa Dua. Pengumpulan data dilakukan melalui kuesioner, dan wawancara. Data yang diperoleh dianalisis dengan teknik analisis deskriptif kualitatif. Hasil dari penelitian ini yaitu (1) buku ajar bahasa Jepang dasar sesuai dengan kebutuhan siswa khususnya untuk siswa kelas V SD Tunas Kasih Nusa Dua, (2) berdasarkan hasil uji ahli isi buku yang dikembangkan dinilai sangat sesuai dan uji ahli desain dinilai sesuai (3) serta hasil respons guru dan siswa SD Tunas Kasih Nusa Dua menunjukkan bahwa buku yang dikembangkan sangat sesuai.
\end{abstract}

Kata kunci: buku ajar Bahasa Jepang, kurikulum KTSP, penelitian dan pengembangan (R\&D)

\section{要旨要旨}

本研究はR\&Dであり、

ヌサジア・トゥナスカシー小学校の五年生を向け、KTSPカリキュラムと日本

語のシラバスを基にした教科書をを作成することを目的としたものである。

調査では、4-

Dモデルを使用した。調査協力者は、日本語教師とヌサヅア・トゥナスカシ 一小学校の五年生である。調査方法は、アンケート及びインタビューである 。このデータを定性的記述法により分析した結果、

1 ） ヌサジア・トゥナスカシー小学校の五年生にとっては、作成した日本語 教科書が、学生のニーズと応じた。2）専門家によるテスト結果に基づき、 開発された本の内容は非常に適切とみなさ。3）本を開発した小学校教師と 生徒のヌサジア・トゥナスカシーの応答は非常に適しています。 キーワード：日本語教科書, KTSPカリキュラム、調査開発研究（R\&D）

\section{Pendahuluan}

Pada era ekonomi ASEAN ini, banyak negara di asia yang menjalin kerja-sama dengan Indonesia. Salah satunya adalah negara Jepang, Jepang adalah mitra strategis In-donesia di berbagai bidang. Negara Jepang juga akan berkontribusi un-tuk pembangunan di daerahdaerah Indonesia, Jepang memutuskan un-tuk menciptakan kesempatan bisnis dengan nilai total sekitar 74 miliar Yen untuk bidang irigasi dan konversasi pantai, kata PM Abe. Selain itu banyak lagi kerjasama Indonesia dan Jepang, seperti pem-bangunan kereta api cepat Jakarta-Surabaya. Hal ini menunjukan pen-tingnya bahasa Jepang untuk di-pelajari di sekolah, selain pelajaran bahasa Inggris sebagai pelajaran internasional. 
Pentingnya pelajaran bahasa jepang juga telah dibuktikan dengan dijadikannya pelajaran bahasa Je-pang sebagai salah satu mata pelajaran tambahan di SD Tunas Kasih Nusa Dua. Sekolah ini me-rupakan sekolah yang memberikan kebebasan untuk siswanya berkreasi, aktif, dan mampu untuk menggali keingintahuan siswa tersebut sendiri. Anak-anak lebih diajarkan untuk pembentukan karakter yang baik. Banyak mata pelajaran ekstra yang ada di sekolah ini, pelajaran bahasa Jepang diberikan kepada siswa diharapakan agar dapat mengem-bangkan potensi yang dimiliki siswa. siswa dan siswinya telah diberikan mata pelajaran bahasa Jepang sejak kelas 1 SD. Dari hasil wawancara bersama guru pengampu yang telah dilakukan pada SD Tunas Kasih Nusa Dua, diketahui bahwa kesulit-an belajara bahasa Jepang ter-jadi pada tingkat kelas V SD. Masalah yang dialami oleh siswa kelas $\mathrm{V}$ adalah semakin rumitnya pelajaran yang dibahas dan penambahan ma-teri tentang pola kalimat yang ber-beda dengan pola kalimat bahasa Indonesia, selain itu juga siswa me-miliki kesulitan untuk mendapatakan metri pelajaran bahasa Jepang, di-kerenakan sekolah masih meng-gunakan metode yang sederhana untuk menunjang proses pem-belajaran.

Proses pembelajaran me-rupakan keseluruhan kegiatan yang dirancang untuk mengajar peserta didik. pada satuan pendidikan, proses pembelajaran diselenggara-kan secara interaktif, inspiratif, me-nyenangkan, mentang, memotivasi peserta didik untuk berpartisipasi aktif sesuai dengan bakat, minat dan perkembangan fisik peserta didik (Mulyasana, 2012). Proses pem-belajaran tidak luput dari media pembelajaran. Media pembelajaran dalam proses pembelajaran dan me-ngajar cendrung diartikan sebagai alat grafis, photografis, atau elek-tronik untuk menangkap, mem-proses, dan menyusun kembali in-formasi visual atau verbal. AECT (Association of Education and Communicattion Technologi) mem-beri batasan tentang media sebagai segala bentuk saluran yang digunakan untuk menyampaikan pesan atau informasi. Disamping se-bagai sistem pengampaian atau pengantar, media yang sering di-ganti dengan kata mediator, dengan istilah mediator media menunjukan fungsi atau perannya, yaitu me-ngatur hubungan yang efektif anatara dua pihak utama dalam proses belajar, yaitu siswa dan isi pelajaran. Ringkasnya media pem-belajaran adalah alat yang menyam-paikan atau mengantarkan pesan-pesan pengajaran (Arsyad, 2010:3). Media pembelajaran bisa dipahami sebagai media yang digunaka dalam proses dan tujuan pembelajaran. Pada hakikatnya proses pembelajaran juga merupakan komuni-kasi, maka media pembelajaran bisa dipahami sebagai media komunikasi yang digunakan dalam proses kemu-nikasi tersebut, media pembelajaran memiliki peran yang penting sebagai sarana untuk menyalurkan proses pembelajaran.

Buku merupakan salah satu media pembelajaran dan mendorong proses belajar yang memegang peran penting dalam proses pem-belajaran dan menjadi salah satu faktor yang berpengaruh terhadap peningkatan mutu pendidikan di sekolah. Berdasarkan kuisioner yang telah disebarkan kepada siswa kelas V SD Tunas Kasih Nusa Dua, dan hasil wawancara terhadap guru pengajar mata pelajaran bahasa Jepang pada tanggal 2 Maret 2017, diketahui bahwa siswa kelas V SD Tunas Kasih Nusa Dua memiliki bahan ajar yaitu modul. Modul yang digunakan oleh siswa sebagai media pembelajaran dibuat sendiri oleh guru pengajar dari mata pelajaran bahasa Jepang. Namun ada keku-rangan pada modul yang dibuat yaitu, kurangnya pembahasan dari meteri dan kurang gambar yang ada di modul, guna menarik minat siswa untuk belajar bahsa Jepang. Selain itu siswa mengalami kesulitan dalam belajar bahasa menggunakan modul tanpa buku ajar sebagai pegangan dalam proses pembelajaran adalah sebagai suatu pegangan dalam menentukan metode pembelajaran.

Berdasarkan hasil kuesioner pengembangan buku ajar, siswa di SD Tunas Kasih Nusa Dua menya-takan bahwa bahan ajar sangat diperlukan dalam belajar bahasa Jepang dan juga dapat mempe-ngaruhi kemampuan siswa dalam belajar bahasa Jepang. Buku ajar sangat penting artinya bagi guru maupun siswa dalam proses belajar mengajar. Dengan adanya buku ajar yang menarik, siswa akan dapat belajar secara mandiri, siswa juga dapat mempelajari materi terlebih dahulu sebelum dibahas di kelas. Buku ajar akan membantu siswa memahami materi yang disampaikan oleh guru. Dengan adanya buku ajar beberapa masalah yang telah disampaikan oleh siswa akan dapat diatasi. 
Penelitian yang relevan per-nah dikajikan sebelumnya oleh Riani (2014) dikembangkan bahan ajar bahasa Jepang menggunakan me-tode dan teknik pembelajaran ga-bungan dari metode GTM (Gra-mmar Translation Method) dan TPR (Total Physical Response). Subjek penelitiannya dilakukan pada siswa kelas 1 Sekolah Dasar dan model penelitian pengembangan yang di-gunakan sebagai pedoman pengem-bangan buku ajar adalah Dick \& Carey. Sedangkan, Widyaningsih (2016) me-ngembangkan bahan ajar bahasa Jepang berbasis pendekatan saintifik. Subjek penelitiannya dila-kukan pada siswa kelas XI SMK PGRI Payangan dan model pene-litian pengembangan yang dilakukan menggunakan model 4D (four D models) dari Thiagarajan, dkk. (1974).

Berdasarkan permasalahan tersebut penelitian ini akan mem-buat produk behan ajar berupa buku ajar untuk siswa kelas V SD. Produk ini dibuat karena diperlukan oleh guru pengajar dan siswa kelas V SD Tunas Kasih Nusa Dua. Selain itu buku ajar yang dibuat kan digunakan untuk mengembangkan kemampuan siswa secara keberlanjutan dalam proses belajar mengajar bahasa Jepang. Sehingga nantinya buku ini akan menjadi penunjang proses pembelajaran dan keterampilan ber-bahasa Jepang pada tingkat beri-kutnya.

Penelitian ini dilakukan kare-na terdapat masalah yaitu proses belajar mengajar bahasa Jepang dengan menggunakan modul. Ter-dapat keter-batasan materi, latihan soalsoal dan kurangnya ilustrasi gambar yang menjelaskan kosakata. selama ini guru dan siswa me-ngalami kesulitan dalam proses belajar dan mengajar dikarenakan kurangnya buku penunjang berupa buku ajar sebagai sumber belajar siswa, yang sesuai dengan dasar-dasar pelajaran bahasa Jepang. Karena adanya keterbatasan materi yang diberikan melalui modul, maka diperlukan buku ajar sebagai penu-jang pelajaran bahasa Jepang.

Dari latar belakang yang telah dijelaskan, pembatas masalah pada penelitian ini adalah dapat mengem-bangkan buku ajar bahasa Jepang bagi siswa kelas V SD tunas Kasih Nusa Dua.

Sesuai dengan rumusan masa-lah yang telah dijabarkan, maka tujuan penelitian ini adalah untuk mengem-bangkan buku ajar bahasa Jepang yang sesuai dengan kurikulum mata pelajaran bahasa Jepang di SD Tunas Kasih Nusa Dua.

Penelitian ini diharpakan mam-pu mengembangkan bahan ajar berupa buku ajar yaitu pengem-bangan buku ajar bahasa Jepang bagi siswa kelas V SD Tunas Kasih Nusa Dua.

Pentingnya Pengembangan

Adapun pentingnya yang diha-rpakan dalam penelitian ini adalah sebagai berikut 1. Bagi sekolah

Adapun manfaat yang dapat di-peoleh sekolah yaitu dapat sebagai pedoman untuk melangsungkan pro-ses belajar mengajar.

2. Bagi guru

Membantu guru yang berperan dalam proses belajar mengajar agar mempermudah penyampaian materi saat pembelajaran berlangsung.

3. Bagi siswa

Membantu siswa untuk mema-hami materi yang disampaikan oleh guru saat proses belajar mengajar, membantu siswa menguji pema-hamannya terhadap materi yang dipelajari dan menjadi pedoman be-lajar siswa secara mandiri.

Bahan ajar bahasa Jepang me-rupakan buku ajar yang akan dikembangkan dalam penelitian ini untuk menunjang proses pembe-lajaran bahasa Jepang. Buku ajar ini disusun berdasarkan standar na-sional pendidikan (komponen kela-yakan isi, komponen kelayakan pe-nyajian, komponen kelayakan kega-fikan dan komponen kelayakan bahasa), analisis kebutuhan, kuri-kulum mata pelajaran bahasa Je-pang kelas V SD Tunas Kasih Nusa Dua.

\section{Metode}

Penelitian ini menggunakan metode penelitian dan pengem-bangan atau yang sering disebut dengan Research and Development (R\&D). Tujuan dari penelitian ini untuk mengembangkan suatu pro-duk yang dapat digunakan dalam pembelajaran. Pengembangan ba-han ajar ini didasarkan pada model pengem-bangan four $D$.

Pengembangan ini menggu-nakan rancangan penelitian Re-search and Development dengan model 4D atau four D dari Thiangarajan, dkk (1974:5). Ter-dapat empat tahap yaitu: 
Define (pendefinisian), Design (perenca-naan), Develop (pengembangan), Disseminate (penyebaran). Dalam artikel yang dibuat Novwaril dan Sri (2015) sudah melakukan pengembangan perangkat four $D$ atau 4D yang dimodifikasi menjadi 3D. Modifikasi yang dimaksud dengan tidak menyertakan proses Dissemi-nate (penyebaran). Sehingga four D Model hanya men-jadi 3D (three D) yang sudah dimodifikasi.

penelitian ini dilakukan berdasarkan dari analisis kurikulum sesuai dengan sekolah di SD Tunas Kasih Nusa Dua. Kegia-tan belajar mengajar meliputi kebu-tuhan dari guru saat mengajar, lalu kesesuaian tema dengan kurikulum, kesesuian buku dengan tema, menekankan dunia nyata, kegiatan belajar mengajar yang menyenang-kan, dan menunjang terlaksananya suatu kegiatan belajar dan mengajar bervariasi. Adanya variasi kegiatan belajar dan mengajar maka akan meningkatkan aspek inovasi pening-katan kegiatan belajar dan mengajar. Pada penelitian ini desain yang digunakan untuk mengembangkan silabus dan membuat buku pelajaran bahasa Jepang. Kemudian akan direvisi oleh para ahli bahasa Je-pang dan guru bahasa Jepang di SD Tunas Kasih Nusa Dua, dan juga dosen pembimbing serta penguji ahli. Dari gambar 3.1 hasil dari bagan tersebut adalah bahan ajar Bahasa Jepang untuk kelas V SD.

Thiagarajan, dkk (1974:5) menyatakan bahwa ada 4 tahap pelaksanaan teknik penelitian dan pengembangan yang sesuai dengan teori four $D$ yaitu :

$1 . \quad$ Define (pendefinisian),

Tahap define (pendefinisian) merupakan tahap untuk mene-tapkan dan mendefinisikan syarat-syarat yang dibutuhkan dalam pe-ngembangan pembelajaran (Thiaga-rajan, dkk, 1974:5). Dalam tahap ini telah dilakukan wawancara secara terstruktur terhadap guru mata pela-jaran bahasa Jepang di SD Tunas Kasih Nusa Dua yang dilakukan 1 kali pada tanggal 24 September 2017. Setelah itu, dilakukan analisis terhadap kurikulum serta silabus yang digunakan untuk menyesuai-kan kebutuhan guru dengan silabus dan kurikulum di sekolah SD Tunas Kasih Nusa Dua. Selanjutnya, pe-nentuan tema pada buku yang akan dikembangkan untuk mencapai stan-dar kompetensi dan kompetensi da-sar yang ingin dicapai.

2. Design (perancangan),

Menurut Thiagarajan, dkk (1974:7), tahap perancangan bertujan untuk merancang perangkat pembelajaran berupa buku ajar. Terdapat empat lang-kah yang harus di-lakukan pada tahap ini, yaitu (1) penyusunan standar tes (criteriontest construc-tion), (2) pemilihan media (media selection) yang sesuai dengan karakteristik materi dan tujuan pem-belajaran, (3) pemilihan format (for-mat selection), yakni mengkaji for-mat bahan ajar yang dikembangkan, dan (4) membuat rancangan awal (initial design) sesuai format yang dipilih.

3. $\quad$ Develop (pengembangan), dan di-sseminate (penyebaran).

Menurut Thiagarajan, dkk (1974:8), tahap pengembangan adalah tahap untuk menghasilkan produk pengembangan yang dilaku-kan melalui dua langkah, yaitu (1) penilaian ahli (expert appraisal) yang diikuti dengan revisi, (2) uji coba pengembangan (develop-menttal testing). Proses ini dimaksudkan untuk memvalidasi atau menilai kelayakan rancangan produk pada pene-litian dan pengembangan ini. Ada-pun aspek penilaian yaitu mencakup aspek materi, penyajian, kegrafikaan dan kebahasaan. Dalam penelitian ini yang melakukan validasi produk yang dikembangkan adalah ahli desain dan ahli isi materi bahasa Jepang.

Pada desain uji coba, dalam mengembangkan bahan ajar bahasa Jepang bagi siswa kelas V SD Tunas Kasih Nusa Dua menggu-nakan desain deskriptif yang diuji validitasnya hingga tahap uji ahli desain dan ahli isi. Tinjauan dari uji ahli dimaksudkan untuk memperoleh penilaian, saran, dan pendapat ter-hadap validasi isi bahan ajar yang dikembangkan.

Berdasarkan tahap develop yang sudah dijelaskan pada langkah-langkah pengembangn four $\mathrm{D}$ yang harus melewati tahap validitas ahli atau praktisi. Validasi ahli adalah teknik yang digunakan untuk menilai kelayakan produk, kemudian produk diperbaiki berda-sarkan saran dari pakar ahi. Peni-laian para ahli/praktisi terhadap pe-rangkat pembelajaran mencakup: format, bahasa, ilustrasi dan isi. 
Uji coba terbatas ini akan dilakukan oleh guru mata pelajaran bahasa Jepang Sehingga diketahui hubungan antara materi dengan kurikulum dan silabus yang akan diajarkan.

Subjek pada uji ahli isi pro-duk penelitian ini adalah dosen Pendidikan Bahasa Jepang, dimana dosen akan menguji kelayakan me-ngenai isi dari materi bahasa Jepang pada produk yang di uji. Uji ahli digunakan untuk mengetahui me-ngenai kelayakan isi, materi dan desain dari produk yang ditawarkan yaitu buku ajar bahasa Jepang untuk anak kelas V SD. Uji ahli desain akan dilakukan oleh dosen dari Jurusan Desain Komunikasi Visual (DKV) Universitas Pendidikan Ganesha.

Jenis data penelitian ini adalah data skala kecil dengan menggunakan angket, data yang dikumpulkan merupakan penilaian, tanggapan, dan saran-saran, yang diperoleh dari para ahli desain dan ahli isi bahasa Jepang di Program Studi Pendidikan Bahasa Jepang dan guru bahasa Jepang di SD Tunas Kasih Nusa Dua. Data terse-but digunakan untuk merevisi produk yang dikembangkan.

Instrumen pengumpulan data dalam penelitian pengembangan ini yaitu instrumen yang dipakai seba-gai alat untuk mengukur validitas dan efektivitas dari rancangan yang telah dibuat. Penelitian ini menggu-nakan dua instrumen penelitian yang digunakan untuk mengumpulkan dan menganalisis data, yaitu wawancara dan angket.

\section{Wawancara}

Wawancara yang dilakukan dalam penelitian ini yaitu dengan guru mata pelajaran bahasa Jepang di SD Tunas Kasih Nusa Dua sebagai respondennya. Wawancara dilaku-kan secara berstruktur. Wawancara dilakukan 1 kali di SD Tunas Kasih Nusa Dua pada tanggal 14 September 2017.

2. Angket

Pada penelitian ini angket digunakan pada saat menganalisis proses uji coba terbatas, uji ahli isi dan desain.

Data kuantitatif berupa penilaian va-lidator, praktisi, dan siswa dianalisis dengan deskriptif kuantitatif. Teknik analisis ini digunakan untuk mengo-lah data yang diperoleh melalui ang-ket dalam bentuk deskriptif kualitatif.

Data yang dikumpulkan dari instrumen yang telah diisi oleh responden ditabulasikan. Selanjut-nya data informasi yang diperoleh dari instrumen angket dianalisis dengan pendekatan deskriptif kuali-tatif.

\section{Hasil dan Pembahasan}

Buku yang dikembangkan adalah buku ajar bahasa Jepang bagi siswa kelas $V$ SD Tunas Kasih Nusa Dua. Buku ini menyajikan materi berupa pengenalan angka-angka dalam bahasa Jepang, jenis-jenis kenda-raan, nama-nama binatang, kalender dan pakaian. Selain itu, terdapat penggunaan pola kalimat, latihan dasar, dan contoh percakapan. Serta di halaman akhir ada ulasan tentang kebudayaan Jepang.

Buku ajar ini digunakan untuk 2 se-mester yaitu semester ganjil dan genap. Buku ini terdiri dari 5 bab yang disusun sesuai dengan analisis kebutuhan melaui wawancara serta silabus semester 1 dan 2. Terdiri dari 5 bab yang dibagi menjadi dua bagian yaitu bab 1, 2 dan 3 semester ganjil dan 4 serta 5 di semester genap dengan memuat materi yang pertama bab 1 Suuji 2, bab 2 Norimono 2, bab 3 Doubutsuen, bab 4 Karendaa, bab 5 Fuku.

Buku ini disusun dengan meng-gunakan huruf romaji karena buku ajar bahasa Jepang untuk sekolah dasar yang materi dan pemaparannya masih bersifat seder-hana dan mudah dimengerti oleh siswa kelas V sekolah dasar Tunas Kasih Nusa Dua. Selain itu, sesuai dengan hasil wawancara bersama guru bahasa Jepang di SD Tunas Kasih Nusa Dua bahwa belum dikenalkannya huruf Hiragana dan Katakana untuk siswanya. Selanjut-nya, gambar dan foto yang diguna-kan digunakan merupakan gambar asli yang dibuat dan diambil secara langsung, bukan merupakan gambar dari sumber lain untuk mengurangi salah persepsi makna dalam peng-gunaan buku tersebut.

Berdasarkan latar belakang yang telah dipaparkan pada bab I, penelitian ini dilakukan karena sampai saat ini belum tersedianya buku ajar di SD Tunas Kasih Nusa Dua untuk buku pemula yang baru mengenal bahasa Jepang. Sesuai dengan teori pengembangan menu-rut Tiagarajan, dkk (1974), analisis ujung depan bertujuan untuk memunculkan dan 
menetapkan ma-salah dasar yang dihadapi dalam pembelajaran, sehingga buku ajar ini perlu dikembangkan sebagai bahan ajar yang sesuai dengan kebutuhan penggunanya. Penilaian angket menggunakan penilaian skala 5 yakni Sangat Sesuai ( SS) $=5$, Sesuai (S) $=4$, Kurang Sesuai $(\mathrm{KS})=3$, Tidak Sesuai $(T S)=2$, Sangat Tidak Sesuai $(\mathrm{STS})=1$.

Berdasarkan hasil penyajian angket dalam tahap validasi uji ahli isi dan uji ahli desain, hasil validasi menunjukkan bahwa tingkat validasi uji ahli isi berada pada kualifikasi sangat sesuai, sedangkan hasil uji ahli validasi uji ahli desain berada pada kualifikasi sesuai. Sehingga dapat disimpulkan bahwa buku ini sudah layak dan sesuai. Buku ini dirancang dikarenakan ditemukan-nya suatu masalah sehingga peneliti berkeinginan mengembangkan se-buah buku ajar yang dibutuhkan sesuai dengan permasalahan yang ada di SD Tunas Kasih Nusa Dua.

Dari hasil wawancara yang dilakukan kepada guru mata pela-jaran bahasa Jepang di SD Tunas Ksih Nusa Dua menjelaskan bahwa sekolah masih mengalami masalah karena bahan ajar yang digunakan masih belum sesuai dengan kebutuhan siswa sekolah dasar. Bahan ajar sebelumnya menggu-nakan modul, materi dari internet di kumpulan dan dijadikan modul oleh guru mata pelajaran bahasa Jepang.

Guru bahasa Jepang di SD Tunas Kasih Nusa Dua menjelaskan bahwa pengembangan buku ajar bahasa Jepang untuk sekolah dasar sangat diharapkan karena penge-nalan bahasa Jepang dasar yang paling sederhana paling tepat diper-kenalkan kepada siswa SD Tunas Kasih Nusa Dua. Banyaknya buku yang beredar dipasaran namun tidak ada sesuai untuk siswa sekolah dasar yang baru mengenal bahasa Jepang.

Buku yang dikembangkan me-nurut kurikulum dan silabus yang berlaku di SD Tunas Kasih Nusa Dua. Kurikulum yang digunakan adalah Kurikulum Tingkat Satuan Pendidikan (KTSP). Menurut Wulan-dari (2012) secara umum diterap-kannya KTSP adalah untuk meman-dirikan dan memberdayakan satuan pendidikan melalui pemberian kewe-nangan (otonomi) kepada lembaga pendidikan dan mendorong sekolah untuk melakukan pengambilan kepu-tusan secara partisipatif dalam mengembangan kurikulum. Silabus yang dikembangkan berpatokan pada kurikulum yang berlaku di SD Tunas Kasih Nusa Dua. Buku ajar yang dikembangkan berdasarkan kebutuhan dan standar kompetensi yang akan dipakai pedoman dalam mengembangkan buku ajar.

Selain itu, materi yang disajikan sudah disesuaikan dengan cakupan aspek pengetahuan, kete-rampilan dan sikap. Materi disajikan agar siswa aktif dan kreatif di kelas dan meningkatkan keingintahuan dalam mempelajari buku bahasa Je-pang tingkat dasar yang akan dikem-bangkan.

Silabus juga digunakan se-bagai acuan dalam pengembangan buku ajar ini. Sehingga buku dapat memenuhi standar kompetensi dan kompetensi dasar pada silabus. Ter-dapat empat kompetensi yang harus dicapai sesuai dengan silabus yanh ada di SD Tunas Kasih Nusa Dua yaitu kompetensi membaca, men-dengar, berbicara dan menulis.

Selain itu materi tentang bahasa Jepang untuk sekolah dasar disesuaikan dengan tingkat kemam-puan siswa di SD Tunas Kasih Nusa Dua, karena pada teori four D ada tahap pendefinisisan dalam pengem-bangan produk terdapat analisis siswa. sehingga buku ajar yang disusun disesuaikan dengan karak-teristik siswa dan kebutuhan siswa kelas $V$ di SD Tunas Kasih Nusa Dua.

Buku bahasa Jepang sekolah dasar ini juga telah disusun ber-dasarkan tahap dari pengembangan four D yaitu (Define) di sekolah SD Tunas Kasih Nusa Dua. Setelah itu melakukan wawancara terhadap guru mata pelajaran bahasa Jepang, an-alisis kurikulum dan silabus di sekolah SD Tunas Kasih Nusa Dua. Tahap kedua yaitu perancangan (Design) yaitu melakukan penentuan format buku ajar. Tahap ketiga pengem-bangan (Develop) yaitu me-lakukan penulisan buku ajar sesuai tema, melakukan validitas ahli isi oleh dosen di program studi bahasa Jepang dan uji ahli desain oleh dosen di program studi Desain Komunikasi Visual. Tahap ter-akhir penyebaran (Disseminate) tidak dila-kukan karena keterbatasan waktu penelitian.

Buku ajar yang baik memenuhi 3 komponen kelayakan, yaitu kom-ponen kelayakan isi, kelayakan ke-bahasaan, dan kelayakan penyajian (Isnawati, 2012). Buku ini sudah layak digunakan sebagai buku ajar untuk siswa kelas V di SD Tunas Kasih Nusa Dua. Kelayakan 
peng-gunaan bahasa Jepang pada buku ini sudah dinilai oleh ahli isi yang merupakan salah satu dosen pen-didikan bahasa Jepang di Uni-versitas Pendidikan Ganesha. Kela-yakan penyajian buku ajar ini juga sudah dinilai oleh ahli desain yang merupakan salah satu dosen Desain Komunikasi Visual di Universitas Pendidikan Ganesha. berikut.

Secara umum manfaat dari buku ajar ini sebagai produk penilaian adalah sebagai

1. Kebutuhan bahan ajar berupa buku ajar bahasa Jepang untuk siswa kelas $\mathrm{V}$ SD Tunas Kasih Nusa Dua.

2. Guru tidak perlu mengumpulkan materi dasar bahasa Jepang dalam proses belajar mengajar karena belum tentu materi-materi yang didapat sesuai dengan level siswa sekolah dasar. Sehingga buku ini dikembangkan berdasarkan dengan silabus di SD Tunas Kasih Nusa Dua.

Adapun kelebihan buku ajar bahasa Jepang untuk siswa sekolah dasar yang dikembangkan adalah sebagai berikut.

1. Buku ajar bahasa Jepang untuk siswa sekolah dasar dapat pengan-tar yang memberikan in-formasi singkat terkait materi yang akan dipelajari. Informasi tersebut memberikan gambaran awal yang dapat memberikan informasi penting ke-pada siswa mengenai kegiatan yang akan dilakukan pada setiap bab.

2. Buku ajar bahasa Jepang untuk siswa sekolah dasar menyajikan kosakata dilengkapi dengan gambar dan ilustrasi yang berwarna bertujan agar menarik siswa siswa belajar bahasa Jepang.

3. Latihan soal yang sajiakan setiap bab disesuaikan dengan materi dan diberikan ilustrasi gambar agar meningkatkan keterampiran siswa menulis, berbicara, membaca dan siwa mendengar sesuai dengan pencapaian standar kompetensi dan kompetensi dasar yang ingin dicapai di silabus.

Adapun kelebihan buku ajar bahasa Jepang untuk siswa sekolah dasar yang dikembangkan adalah sebagai berikut.

1. Buku ajar bahasa Jepang untuk siswa sekolah dasar dapat pe-ngantar yang memberikan informasi singkat terkait materi yang akan dipelajari. Informasi tersebut memberikan gambaran awal yang dapat memberikan informasi penting ke-pada siswa mengenai kegiatan yang akan dilakukan pada setiap bab.

2. Buku ajar bahasa Jepang untuk siswa sekolah dasar menyajikan kosakata dilengkapi dengan gam-bar dan ilustrasi yang berwarna bertujan agar menarik siswa siswa belajar bahasa Jepang.

3. Latihan soal yang sajiakan setiap bab disesuaikan dengan materi dan diberikan ilustrasi gambar agar meningkatkan keterampilan siswa menulis, berbicara, membaca dan siwa mendengar sesuai dengan pencapaian standar kom-petensi dan kompetensi dasar yang ingin dicapai di silabus.

Tanggapan guru bahasa Jepang di SD Tunas Kasih Nusa Dua me-ngungkapkan bahwa buku ajar bahasa Jepang ini sangat menarik untuk minat siswa dalam proses belajar mengajar bahasa Jepang dan adanya buku ajar yang sesuai dengan kemampuan pengetahuan serta karakteristik siswa menim-bulkan sikap kompetitif siswa yang positif. Demikianlah pentingnya buku "Bahasa Jepang Untuk Siswa Kelas V SD Tunas Kasih Nusa Dua" ini di-kembangkan sehingga dapat digu-nakan oleh guru dan siswa sebagai sumber belajar mengejar bahasa Jepang sekolah dasar untuk me-ningkatkan keterampilan berbahasa Jepang.

Berdasarkan hasil pembatasan, peneli-tian dan pengembangan ini memiliki implikasi yaitu buku ajar ini dapat digunakan untuk siswa kelas V SD Tunas Kasih Nusa Dua. Buku ajar ini membantu guru dalam belajar mengajar dalam kelas agar siswa termotivasi belajar bahasa Jepang dan dapat menguasai kosa-kata dasar bahasa Jepang.

Berdasarkan hasil uji ahli yang di-lakukan mendapat penilaian dengan ren-tangan (5) Sangat Sesuai sampai dengan (3) Cukup dan beberapa tahap penyem-purnaan, buku ajar ini sudah layak digunakan sebagai bahan ajar.

\section{Simpulan dan Saran}


Penelitian ini dilakukan kare-na tidak terdapatnya buku ajar ba-hasa Jepang untuk siswa sekolah dasar yang menjadi sumber belajar siswa di SD Tunas Kasih Nusa Dua. Penelitian ini yaitu mengembangkan buku ajar bahasa Jepang untuk siswa sekolah dasar yang dianggap penting untuk dikembangkan, karena selain membantu pengetahuan da-lam pembelajaran disekolah, juga membantu siswa dalam memperoleh keterampilan berbahasa Jepang.

Menguasai bahasa Jepang dasar dianggap penting untuk mem-bantu menjadi penunjang proses pembelajaran dan keterampilan ba-hasa Jepang pada tingkatan berikutnya. Selain itu, membantu guru di SD Tunas Kasih Nusa Dua dalam proses belajar mengajar di kelas.

Buku ajar ini dikembangkan berdasarkan analisis wawancara dan angket yang dilakukan langsung dilapangan. Buku yang disusun ber-dasarkan silabus dan kurikulum yang digunakan di SD Tunas Kasih Nusa Dua dijadikan acuan dalam mengembangkan buku ajar ini.

Buku bahasa Jepang sekolah dasar ini juga telah disusun ber-dasarkan tahap dari pengembangan four $D$ yaitu (Define) yang melakukan wawancara terhadap guru mata pelajaran bahasa Jepang, analisis kurikulum dan silabus di sekolah SD Tunas Kasih Nusa Dua.

Tahap kedua yaitu peranca-ngan (Design) yaitu melakukan pe-nentuan format buku ajar. Tahap ke-tiga pengembangan (Develop) yaitu melakukan penulisan buku ajar se-suai tema, melakukan validitas ahli isi oleh dosen di program studi ba-hasa Jepang, uji ahli desain oleh dosen di program studi Desain Komunikasi Visual dan uji coba ter-batas guru pengajar bahasa Jepang di SD Tunas Kasih Nusa Dua. Tahap terakhir penyebaran (Disseminate) tidak dilakukan karena keterbatasan waktu penelitian.

Simpulan yang dapat diru-muskan yaitu buku ajar yang sesuai dengan kurikulum dan silabus mata pelajaran bahasa Jepang di SD Tunas Kasih Nusa Dua untuk siswa kelas V semester ganjil dan genap adalah buku bahasa Jepang yang terdapat gambar dan ilustrasi yang berwarna agar menarik minat siswa belajar dan memahami kosakata bahasa Jepang. Selain itu, terdapat latihan yang membantu siswa aktif dalam pembelajaran baik dari aspek membaca, menulis, mendengarkan dan berbicara.

Buku ini terdiri dari 5 bab yang disusun sesuai dengan analisis kebutuhan melaui wawancara serta silabus semester 1 dan 2 . Terdiri dari 5 bab yang dibagi menjadi dua bagian yaitu bab 1, 2 dan 3 semes-ter ganjil dan 4 serta 5 di semester genap dengan memuat materi yang pertama bab 1 Suuji 2, bab 2 Norimono 2, bab 3 Doubutsuen, bab 4 Karendaa, bab 5 Fuku. Kemudian setiap bab terdapat latihan yang dapat dikerjakan dikelas, sehingga dapat menjadi bahan evaluasi agar dapat mengetahui seberapa besar pengetahuan yang telah diperoleh siswa.

Berdasarkan hasil temuan dalam penelitian ini, maka akan di-sampaikan saran kepada peneliti lainnya yaitu diharapkan dapat menyusun buku ajar bahasa Jepang untuk sekolah dasar yang lain sesuai dengan kurikulum dan silabus. Buku ajar bahasa Jepang untuk siswa sekolah dasar yang selanjutnya diharapkan dapat menyajiakan caku-pan materi yang lebih luas untuk mengenal bahasa Jepang. Kemu-dian di dalam buku diharapkan terdapat latihanlatihan yang lebih bervariasi dalam membantu pem-belajaran bahasa Jepang tingkat dasar, serta dapat menyusun buku yang lebih baik, menarik dan inovatif.

\section{Daftar Pustaka}

Arsyad, Azhar, Media Pembelajaran, Jakarta: RajaGrafondo Persada, 2013.

Ismawati, Esti. 2012. Telaah Kurikulum dan Pengembangan Bahan Ajar. Yogyakarta: Ombak.

Mulyasana, Dedi. 2012. Pendidikan Burmutu dan Berdaya Saing. Bandung. PT. Remaja Rosdakarya. 
Novwaril, Yusrizal Huda dan Sri, Endang Widayati. 2015. "Pengembangan Media Pembelajaran Berbasis Multimedia pada Materi Memproduksi Pementasan Drama untuk Kelas XI SMA". FKIP, Universitas Jember. Volume 2 No. 1.

Riani, Putu Eka. 2014. Mengembangkan Buku Ajar Bahasa Jepang untuk Siswa Kelas 1 SD 3 Saraswati Denpasar Berjudul "Nihongo o Benkyou Shiyou". Skripsi (tidak diterbitkan). Jurusan Pendidikan Bahasa Jepang Fakultas Bahasa dan Seni, Universitas Ganesha.

Tegeh, I Made, I Made Kirna. 2010. Metode Penelitian Pengembangan Pendidikan. Singaraja: Universitas Pendidikan Ganesha.

Thiagarajan,dkk. 1974. Instructional Development for Training Teachers of Exceptional Children A sourcebook. Indiana: Indiana University Bloomington.

Widyaningsih, Ni Kadek. 2016. Pengembangan Buku Ajar Basa Jepang Pariwisata Berbasis Pendekatan Saintifik untuk Siswa Kelas XI SMK PGRI Payangan. Skripsi (tidak diterbitkan). Jurusan Pendidikan Bahasa Jepang, Universitas Ganesha.

Wulandari, Fitri. 2012. "Implementasi Kurikulum Tingkat Satuan Pendidikan (KTSP) Dalam Pembelajaran Matematika Di SMPLB TPA Jember". MIPA FKIP Universitas Jember, Volume 3, No. 3. 